\author{
Anna Czapkiewicz \\ Akademia Górniczo-Hutnicza w Krakowie \\ e-mail: gzrembie@cyf-kr.edu.pl
}

\title{
Pawel Jamer
}

Szkoła Główna Gospodarstwa Wiejskiego w Warszawie e-mail: pawel.jamer@gmail.com

\section{DYNAMIKA WSPÓŁZALEŻNOŚCI WARSZAWSKIEJ GIEEDY PAPIERÓW WARTOŚCIOWYCH Z INNYMI RYNKAMI FINANSOWYMI}

\section{DYNAMICS OF INTERDEPENDENCE BETWEEN WARSAW STOCK EXCHANGE AND OTHER FINANCIAL MARKETS}

DOI: $10.15611 /$ ekt.2015.2.09

Streszczenie: Badanie współzależności oraz siły związków zachodzących pomiędzy finansowymi szeregami czasowymi jest jednym $\mathrm{z}$ ważniejszych zagadnień $\mathrm{w}$ analizie rynków finansowych. Do modelowania dynamiki wielowymiarowych rozkładów stóp zwrotu często wykorzystuje się modele oparte na wielowymiarowych procesach GARCH. Innym podejściem do zagadnienia jest zastosowanie funkcji kopuli do badania współzależności, gdzie dynamika jest sterowana ukrytym procesem Markowa. Celem pracy jest zbadanie zmian współzależności indeksu WIG z innymi głównymi indeksami światowymi. W tym celu zastosowane zostały oba podejścia. Badanie to pozwoliło wyodrębnić okresy silniejszych i słabszych współzależności rynku polskiego z rynkami finansowymi z różnych rejonów świata: Europy, Azji i Ameryki.

Slowa kluczowe: DCC, Copula-GARCH, ukryty proces Markowa, giełda papierów wartościowych, badanie zależności.

Summary: The aim of this article was the search of the dynamic of dependencies between WSE and other countries coming from Europe, America and Asia. The two-dimensional time series has been modeled by multidimensional GARCH process with dynamic conditional correlation or by Markov-switching Copula-GARCH model. The analysis confirms the claim that dependences between financial markets are higher in a period of crisis than during the prosperity time. The dynamic of relationships between Polish market and European markets is bigger than the dynamic of relationships between Polish market and American or Asian markets.

Keywords: DCC, Copula-GARCH, hidden Markov model, stock exchange, dependence survey. 


\section{Wstęp}

Znajomość współzależności pomiędzy rynkami finansowymi ma szczególne znaczenie m.in. w dywersyfikacji portfela inwestycji. Dysponując wiedzą na ten temat, inwestor może podjąć decyzję dotyczącą rozdziału swojego kapitału tak, by zmniejszyć ryzyko inwestycji. W swojej pracy Grubel [1968] po raz pierwszy zwrócił szczególną uwagę na korzyści płynące z międzynarodowej dywersyfikacji portfela.

W ostatnich latach zaobserwowano wzrost siły współzależności pomiędzy rynkami finansowymi, który jest spowodowany m.in. postępującą globalizacją. W literaturze finansowej dotyczącej badania powiązań między rynkami panuje również pogląd, że współzależność ta jest związana z sytuacją istniejącą na rynkach finansowych i jest silniejsza w okresie bessy niż w okresie hossy. Między innymi Longin i Solnik [1995], badając współzależność miesięcznych stóp zwrotu indeksów giełdowych pochodzących z kilku światowych rynków finansowych, zauważyli, że korelacja między rynkami jest większa w okresie spadków niż w okresie wzrostu. Forbes i Rigobon [2002] zwrócili uwagę na efekt zarażania się rynków, czyli na wystąpienie wyraźnej zmiany pomiędzy powiązaniami na rynkach finansowych w czasach turbulencji. Markwat, Kole i van Dijk [2009] zauważyli, że w czasie kryzysu występuje efekt domina, nasila się powiązanie rynków finansowych, co z kolei wywołuje spadki cen akcji na prawie wszystkich parkietach.

Zagadnienia dotyczące analizy współzależności warszawskiej Giełdy Papierów Wartościowych (GPW) z innymi światowymi rynkami finansowymi podejmowali już w swoich pracach różni autorzy. Pekota [2007] analizował związek rynku polskiego z rynkiem amerykańskim. Ocenie powiązań polskiego rynku kapitałowego z rynkami Czech i Węgier oraz z rynkami rozwiniętymi (europejskim reprezentowanym przez indeks DAX i amerykańskim analizowanym za pośrednictwem indeksu S\&P500) była poświęcona praca Doman i Doman [2013]. W swojej pracy Hołubowicz [2014] badał korelację liniową WIG z innymi indeksami giełdowymi w okresie 1999-2011 w różnych przedziałach czasowych. Wyniki badań dotyczące zmiany powiązania indeksu GPW z innymi światowymi indeksami w różnych okresach przedstawione były również w pracy Czapkiewicz i Basiury [2014].

$\mathrm{W}$ celu zbadania dynamiki zmian zależności zachodzących pomiędzy rynkami finansowymi reprezentowanymi przez notowania indeksów giełdowych można zastosować wybrane modele dynamiczne, na których podstawie można wskazać okresy silnej i słabej zależności. Modele te zazwyczaj stosuje się do opisu szeregów czasowych utworzonych $\mathrm{z}$ dziennych stóp zwrotu rozważanych indeksów giełdowych reprezentujących dany rynek finansowy.

W literaturze przedmiotu spotykamy propozycje różnych modeli dynamicznych służących do opisu wielowymiarowych szeregów czasowych będących stopami zwrotu indeksów badanych rynków. Na przykład Longin i Solnik [1995] do swoich badań zastosowali wielowymiarowy model $\operatorname{GARCH}(1,1)$. Engle [2002] oraz Tse i Tsui [2002] rozważali modele GARCH, w których warunkowa korelacja jest dy- 
namiczna (model DCC). Innym podejściem do opisu dynamiki zależności, które występują w literaturze, są modele wykorzystujące teorię funkcji kopuli, w których dynamika zmian sterowana jest ukrytym procesem Markowa. Między innymi zagadnieniom tym poświęcone są prace Pattona [2009], Jondeau i Rockingera [2006], Rodrigueza [2007], Chollete'a, Heinena i Valdesogo [2009], Kenourgiosa, Samitasanda i Paltalidisa [2011] i innych. Dwa stany ukrytego procesu Markowa są utożsamiane $\mathrm{z}$ okresami hossy i bessy na rynkach finansowych.

Celem tego artykułu jest zbadanie dynamiki zmian współzależności indeksu WIG z innymi indeksami światowymi w okresie od 2004 roku do końca 2014 roku. Badanie ma na celu potwierdzenie panującej tezy, że w okresie kryzysu zwiększyły się powiązania pomiędzy rynkami finansowymi. Prawidłowość ta mocniej zachodzi $\mathrm{w}$ trakcie analizy powiązań WIG z indeksami giełdowymi pochodzacymi z rynków europejskich niż $\mathrm{w}$ analizie powiązań $\mathrm{z}$ rynkami azjatyckimi i rynkiem amerykańskim. W prezentowanej pracy badana jest również możliwość istnienia innych przyczyn wpływających na zmianę siły współzależności warszawskiej GPW z innymi rynkami, które niekoniecznie są związane z okresami kryzysu.

Do badania wybrano indeksy reprezentujące rynki finansowe Europy Zachodniej, Europy Wschodniej oraz Azji i Ameryki. Dynamikę modelowano z wykorzystaniem trzech podejść: wielowymiarowego modelu GARCH (model DCC) oraz modelu Copula-GARCH sterowanego procesem Markowa o dwóch oraz trzech stanach.

\section{Modele dynamiczne}

Jak wspomniano we wstępie, do opisu dynamicznej współzależności pomiędzy szeregami czasowymi utworzonymi $\mathrm{z}$ dziennych stóp zwrotu indeksów giełdowych można zastosować dwa podejścia: wielowymiarowy model GARCH oraz przełącznikowy model Copula-Garch. Wielowymiarowy model GARCH wymaga jednak pewnych założeń dotyczących wielowymiarowych rozkładów. Pomimo że w literaturze przedmiotu dotyczących tego modelu pojawiają się próby ominięcia tych krępujących założeń, które występują w finansowych szeregach czasowych (na przykład: asymetria występująca w szeregach czasowych), to alternatywnymi modelami stosowanymi do badania dynamiki są modele przełącznikowe Copula-Garch, w którym przełączenie sterowane jest ukrytym procesem Markowa $\mathrm{z}$ dwoma reżimami. Pomimo że model ten nie ilustruje pełnej zmiany zależności, a tylko pozwala na wskazanie stanów, w którym występuje duża i mała korelacja, to jednak umożliwia dokładne modelowanie rozkładów brzegowych i uwzględnienie ich specyficznych własności. W celu lepszej ilustracji dynamiki można natomiast w modelu uwzględnić większą liczbę stanów. 


\subsection{Model VAR(1)-GARCH(1,1)}

Rozważmy $N$ wymiarowy szereg czasowy $r_{t}$ spełniający zależność VAR(1):

$$
r_{t}=\mu+A r_{t-1}+\varepsilon_{t}
$$

gdzie $\mu$ oraz $A$ oznaczają odpowiednio wektor stałych oraz macierz parametrów autoregresji, natomiast $\varepsilon_{t}$ oznacza wektor zaburzeń losowych. $O$ wektorze $\varepsilon_{t}$ zakładamy, że spełnia następującą zależność:

$$
\varepsilon_{t}=H_{t}^{1 / 2} z_{t}
$$

gdzie $H_{t}$ jest dynamiczną macierzą kowariancji oraz

$$
E\left(z_{t}\right)=0, E\left(z_{t} z_{t}^{T}\right)=I_{N} \text { i } z_{t} \sim G\left(0, I_{N}\right) .
$$

Zakładamy również, że $E\left(\varepsilon_{t} \mid \Omega_{t-1}\right)=0$ oraz $E\left(\varepsilon_{t} \varepsilon_{t}^{T} \mid \Omega_{t-1}\right)=H_{t}$, gdzie $\Omega_{t-1}$ oznacza zbiór informacji o szeregu do chwili $t-1$.

Dla macierzy $H_{t}$ przyjęto specyfikację DCC, czyli :

$$
H_{t}=D_{t} R_{t} D_{t}
$$

gdzie $R_{t}$ jest warunkową macierzą korelacji wektora $\varepsilon_{t}$, natomiast $D_{t}=\sqrt{\operatorname{diag}\left(H_{t}\right)}$ jest macierzą diagonalną składającą się $\mathrm{z}$ warunkowych odchyleń standardowych składowych $\varepsilon_{i, t}$, oznaczonych jako $\sqrt{h_{i i, t}}$, gdzie

$$
h_{i i, t}=\omega+\alpha_{i} \varepsilon_{i, t-1}^{2}+\beta_{i} h_{i i, t-1}, i=1,2, \ldots, N .
$$

W modelu DCC przyjmuje się, że

$$
R_{t}=\operatorname{diag}\left(Q_{t}\right)^{-1 / 2} Q_{t} \operatorname{diag}\left(Q_{t}\right)^{-1 / 2},
$$

gdzie

$$
Q_{t}=(1-\alpha-\beta) \bar{Q}+\alpha z_{t-1} z_{t-1}^{T}+\beta Q_{t-1}, a, b \geq 0, \alpha+\beta<1
$$

oraz $z_{t}=D_{t}^{-1} \varepsilon_{t}$. Macierz $\bar{Q}$ oznacza bezwarunkową macierz korelacji błędów $z_{t}$.

W badaniach empirycznych jako rozkład funkcji $G$ przyjęto wielowymiarowy rozkład normalny. Parametry modelu wyznaczono metodą największej wiarogodności.

\subsection{Przelącznikowy model Copula-GARCH}

Funkcja kopuli, zwana również funkcją połączeń $C:[0,1]^{d} \rightarrow[0,1]$, intuicyjnie może być traktowana jako wielowymiarowa dystrybuanta o jednostajnych na przedziale $[0,1]$ rozkładów brzegowych. Jeśli $X=\left(X_{1}, \ldots, X_{d}\right)$ będzie $d$-wymiarową zmienną losową o ciągłej dystrybuancie $F$, to według twierdzenia Sklara [1959] istnieje jednoznaczna funkcja połączeń $C:[0,1]^{d} \rightarrow[0,1]$ taka, że

$$
F\left(x_{1}, \ldots, x_{d}\right)=C\left(F_{1}\left(x_{1}\right), \ldots, F_{d}\left(x_{d}\right)\right),
$$


gdzie $F_{i}\left(x_{i}\right)$ jest dystrybuantą rozkładu brzegowego. Fundamentalny wniosek z twierdzenia Sklara jest taki, że ciągły rozkład wielowymiarowy i rozkłady brzegowe mogą być rozważane osobno, a miara współzależności między nimi może być reprezentowana funkcją połączeń.

Podstawową klasę funkcji połączeń stanowią tzw. kopule eliptyczne, do których należy funkcja połączeń Gaussa i funkcja połączeń $t$-Studenta. Inną klasą funkcji połączeń jest klasa kopuli Archimedesowskich.

W celu wprowadzenia dynamiki do modeli konstruowanych opartych na teorii funkcji kopuli wykorzystuje się często ukryte procesy Markowa, które definiujemy jako parę procesów $\left(S_{t}, R_{t}\right)$, gdzie $S_{t}$ jest nieobserwowalnym łańcuchem Markowa $\mathrm{z}$ przestrzenią stanów $S$ oraz macierzą przejścia $P=\left[p_{i j}\right]_{i, j}$, $p_{i j}=P\left(S_{t}=j \mid S_{t-1}=i\right)$, a $R_{t}$ jest obserwowalnym $k$-wymiarowym szeregiem czasowym.

W modelu przełącznikowym Copula-GARCH przyjmujemy, że warunkowa dystrybuanta dla $R_{t} \mid\left(S_{t}, \Omega_{t-1}\right)$ jest postaci

$$
F\left(r_{t} \mid S_{t}=j, \Omega_{t-1} ; \theta\right)=C_{j}\left(F_{t} \mid \Omega_{t-1} ; \theta_{c}^{j}\right),
$$

gdzie $C_{j}$ jest kopulą dla zmiennych będących w $j$-tym reżimie, a $F_{t}$ jest wektorem wartości dystrybuant rozkładów brzegowych w chwili $t$. Do opisu rozkładów brzegowych przyjęto proces $\mathrm{AR}(1)-\mathrm{GARCH}(1,1) \mathrm{z}$ warunkowym rozkładem skośnym $t$-Studenta.

W badaniu empirycznym rozważano różne funkcje kopuli, które charakteryzują się innymi niż współczynnik korelacji parametrami, niekoniecznie interpretowanymi jako miara współzależności. Zatem jako jednorodną miarę współzależności badanych indeksów giełdowych przyjęto współczynnik Spearmana, którego wielkość jest wyznaczana jako

$$
\rho=12 \iint_{0}^{1} C(u) d u-3 .
$$

W przypadku uwzględnienia dynamiki mamy

$$
E\left(\rho_{t} \mid \Omega_{T}\right)=\sum_{j=1}^{l} \rho_{j} P\left(S_{t}=j \mid \Omega_{T}\right) .
$$

Estymacja parametrów modelu przebiega w dwóch etapach. W pierwszym kroku dokonujemy szacowania parametrów modeli brzegowych, natomiast $\mathrm{w}$ drugim kroku szacujemy parametry funkcji kopuli. Kiedy rozważamy model $\mathrm{z}$ dwoma reżimami, estymacji parametrów kopuli w modelu przełącznikowym dokonujemy metodą największej wiarogodności z zastosowaniem filtru Hamiltona [1994]. W rozważaniu modelu z trzema reżimami do estymacji parametrów kopuli zastosowano algorytm EM. 


\section{Badanie współzależności rynków}

\subsection{Dane}

Badaniem objęto notowania indeksów wybranych giełd światowych od 2004 roku do końca 2014 roku. Na wybór okresu badania wpłynęła data przystąpienia Polski do Unii Europejskiej. W badaniu rozważono indeksy będące reprezentantami rynków finansowych Europy Zachodniej, Europy Wschodniej, Ameryki oraz Azji. Dla tych indeksów obliczono stopy zwrotu, wg formuły

$$
r_{i t}=\ln \frac{P_{i, t}}{P_{i, t-1}},
$$

gdzie $P_{i, t}$ jest ceną zamknięcia $i$-tego indeksu w chwili $t$, natomiast $P_{i, t-1}$ jest ceną zamknięcia $\mathrm{z}$ dnia poprzedniego. Celem ilustracji własności utworzonych szeregów czasowych obliczono dla nich statystyki opisowe i przeprowadzono testy na efekt GARCH. Wyniki zawiera tab. 1.

Tabela 1. Statystyki opisowe dla stóp zwrotu badanych indeksów

\begin{tabular}{|l|c|c|c|c|c|c|c|}
\hline \multicolumn{1}{|c|}{ Kraj } & Indeks & Średnia & $\begin{array}{c}\text { Odchylenie } \\
\text { standardowe }\end{array}$ & Mediana & Kurtoza & Skośność & $\begin{array}{c}\text { Test } \\
\text { Engle'a } \\
(p \text {-value })\end{array}$ \\
\hline Polska & WIG & 0,026 & 1,117 & 0,054 & 4,98 & $-0,49$ & 0,000 \\
\hline Czechy & PX & 0,021 & 1,293 & 0,061 & 20,08 & $-1,00$ & 0,000 \\
\hline Węgry & BUX & 0,015 & 1,427 & 0,044 & 9,19 & $-0,21$ & 0,000 \\
\hline Turcja & XU & 0,063 & 1,635 & 0,097 & 4,65 & 0,08 & 0,000 \\
\hline Niemcy & DAX & 0,025 & 1,262 & 0,072 & 5,71 & $-0,13$ & 0,000 \\
\hline Holandia & AEX & 0,001 & 1,224 & 0,043 & 7,79 & $-0,14$ & 0,000 \\
\hline Francja & CAC & 0,009 & 1,258 & 0,034 & 5,76 & $-0,10$ & 0,000 \\
\hline Anglia & FTSE & 0,044 & 0,993 & 0,082 & 4,97 & $-0,27$ & 0,000 \\
\hline Szwajcaria & SMI & 0,019 & 0,984 & 0,052 & 6,69 & $-0,14$ & 0,000 \\
\hline Hiszpania & IBEX & 0,025 & 1,293 & 0,061 & 6,05 & $-0,23$ & 0,000 \\
\hline Austria & ATX & 0,028 & 1,337 & 0,083 & 7,19 & $-0,34$ & 0,000 \\
\hline USA & SPX & 0,025 & 1,084 & 0,047 & 10,96 & $-0,32$ & 0,000 \\
\hline Indie & SNX & 0,060 & 1,306 & 0,093 & 6,15 & $-0,30$ & 0,000 \\
\hline Hongkong & HSI & 0,018 & 1,288 & 0,050 & 12,95 & 0,32 & 0,000 \\
\hline Indonezja & JCI & 0,098 & 1,211 & 0,099 & 8,24 & $-0,60$ & 0,000 \\
\hline Malezja & KLCI & 0,036 & 0,631 & 0,043 & 5,35 & $-0,41$ & 0,000 \\
\hline Korea & KOSPI & 0,033 & 1,241 & 0,060 & 9,39 & $-0,62$ & 0,000 \\
\hline Chiny & SHBS & 0,024 & 1,611 & 0,043 & 7,17 & $-0,29$ & 0,000 \\
\hline Singapur & STI & 0,025 & 0,974 & 0,051 & 8,80 & $-0,46$ & 0,000 \\
\hline
\end{tabular}

Źródło: opracowanie własne. 
Tabela 1 przedstawia statystyki opisowe dla utworzonych szeregów czasowych. Wartości średniej, mediany i odchylenia standardowego zostały podane $\mathrm{w}$ procentach. Analizując wyniki zamieszczone w tabeli dla wszystkich badanych indeksów, zauważamy większą wartość mediany w stosunku do wartości średniej arytmetycznej, co stanowi podstawę do stwierdzenia o występowaniu asymetrii. Współczynnik asymetrii jest ujemny, co wskazuje na występowanie asymetrii lewostronnej dla prawie wszystkich rozważanych indeksów. Przeprowadzony test Engle'a dla wszystkich danych wskazuje na występowanie efektu GARCH.

Na podstawie wniosków wypływających z powyższej analizy wyników uzyskanych statystyk opisowych można stwierdzić, że wybór modelu $\operatorname{GARCH}(1,1)$ $\mathrm{z}$ rozkładem warunkowym $t$-Studenta służącym do opisu badanych stóp zwrotu jest uzasadniony. Dodatkowo w modelu uwzględniono autokorelację pierwszego rzędu, która występowała w niektórych szeregach czasowych. W celu zbadania adekwatności wyboru modelu AR(1)-GARCH(1,1) dla opisu stóp zwrotu wykorzystano rozumowanie z pracy: Diebold, Gunther i Tay [1989]. Dla większości z rozpatrywanych szeregów czasowych wyniki przeprowadzonych testów były zadowalające.

\subsection{Wyniki estymacji}

Badając dynamikę współzależności pomiędzy stopami zwrotu badanych indeksów giełdowych, zastosowano trzy podejścia, które opisano w poprzednim paragrafie. W wyniku zastosowania modelu VAR(1)-GARCH(1,1) uzyskano dynamikę korelacji między szeregami czasowymi, których graficzna prezentacja jest przedstawiona na rysunkach (rys. 1, 2 i 3).

Drugie podejście do modelowania dynamiki współzależności opiera się na zastosowaniu funkcji kopuli oraz ukrytych procesów Markowa.

$\mathrm{W}$ analizie modelu przełącznikowego Copula-GARCH z dwoma reżimami przyjęto, że przełączenie następuje między dwiema kopulami wybranymi spośród kopul

- eliptycznych: Gaussa, $t$-Studenta,

- Claytona, Gumbela, Franka, Joe, Claytona-Gumbela (BB1), Joe-Gumbela (BB6), Joe-Claytona (BB7), Joe-Franka.

W celu wyboru najlepszej pary spośród analizowanych wszystkich możliwych do utworzenia par funkcji kopuli zastosowano test Vuonga [1989].

Następnie rozważono model $\mathrm{z}$ trzema reżimami. Podejście to miało na celu zwiększenie dynamiki zależności poprzez wprowadzenie stanu przejściowego pomiędzy dwoma stanami. W podejściu tym przyjęto, że przełączenie występuje tylko między kopulami Gaussa, gdyż zwiększenie liczby reżimów pomiędzy funkcjami kopuli jest równoważne ze zwiększeniem problemów technicznych dotyczących estymacji parametrów. W przypadku rozważania innych kopul niż kopula Gaussa algorytmy okazywały się niestabilne.

Jednakże w sytuacji zastosowania modelu $\mathrm{z}$ trzema reżimami uzyskano bardzo krótki czas przebywania w danym reżimie. Stosując ponownie test Vuonga dla po- 
równania modelu $\mathrm{z}$ trzema reżimami i najlepszego modelu $\mathrm{z}$ dwoma reżimami, stwierdzono, że tylko dla kilku badanych par rynków model z trzema reżimami był lepszy (w sensie testu). Dla większości badanych par model z dwoma reżimami był wystarczająco skuteczny. W niektórych przypadkach zależność między badanymi szeregami czasowymi pozostawała $\mathrm{w}$ jednym reżimie.

Tabela 2 przedstawia parametry kopuli Gaussa, dla modelu z trzema, dwoma lub $\mathrm{z}$ jednym reżimem, w zależności od wskazań testu Vounga. W modelu z trzema reżimami jego parametry możemy interpretować jako słabą, umiarkowaną i silną korelację indeksu giełdowego pochodzącego z GPW w Warszawie z indeksami giełdowymi z innych krajów.

Tabela 2. Parametry funkcji kopuli w przełącznikowym modelu Copula-GARCH

\begin{tabular}{|l|c|c|c|}
\hline \multicolumn{1}{|c|}{ Kraj } & $\begin{array}{c}\text { Słaba } \\
\text { zależność }\end{array}$ & $\begin{array}{c}\text { Umiarkowana } \\
\text { zależność }\end{array}$ & $\begin{array}{c}\text { Silna } \\
\text { zależność }\end{array}$ \\
\hline Polska & - & - & - \\
\hline Czechy & 0,41 & 0,59 & - \\
\hline Węgry & 0,34 & 0,58 & - \\
\hline Turcja & 0,02 & 0,50 & 0,68 \\
\hline Niemcy & 0,20 & 0,66 & 0,73 \\
\hline Holandia & 0,41 & 0,42 & 0,80 \\
\hline Francja & 0,47 & 0,61 & 0,94 \\
\hline Anglia & 0,46 & 0,56 & 0,88 \\
\hline Szwajcaria & 0,15 & 0,61 & 0,70 \\
\hline Hiszpania & 0,41 & 0,65 & - \\
\hline Austria & 0,36 & 0,61 & 0,93 \\
\hline USA & 0,21 & - & - \\
\hline Rosja & 0,06 & 0,63 & 0,69 \\
\hline Indie & 0,24 & 0,40 & - \\
\hline Hongkong & 0,30 & - & - \\
\hline Indonezja & 0,29 & - & - \\
\hline Malezja & 0,30 & - & - \\
\hline Korea & 0,21 & 0,43 & - \\
\hline Chiny & 0,12 & - & - \\
\hline Singapur & 0,17 & 0,35 & - \\
\hline & & &
\end{tabular}

Źródło: opracowanie własne.

Analizując wyniki, które przedstawia tab. 2, zauważamy występowanie stosunkowo dużych wartości współczynników korelacji dla par utworzonych z indeksu WIG i indeksu giełdowego z Europy Zachodniej. Dla tych par zauważamy istnienie 
trzeciego stanu, w którym występuje bardzo silna korelacja. Trzeci stan występuje również w powiązaniach rynku polskiego z rynkiem Rosji i Turcji, jednakże współczynniki korelacji w trzecim stanie wydają się tu nieco niższe niż w przypadku krajów Europy Zachodniej. Zależności WIG z indeksami Czech i Węgier oraz zależność WIG z indeksami niektórych krajów azjatyckich pozostają w dwóch stanach. Brak jakiejkolwiek dynamiki zmian zależności zaobserwowano dla przypadku analizy WIG z indeksem giełdy amerykańskiej oraz z indeksami niektórych rynków Azji, takimi jak Hongkong, Indonezja, Malezja czy Chiny.

Wartości parametrów przedstawione w tab. 2 nie ukazują w pełni zmian współzależności, którą najlepiej przedstawić graficznie. Dynamiczny współczynnik korelacji Spearmana jest uniwersalnym narzędziem pozwalającym na ilustrację tych zmian, zwłaszcza gdy w modelu przełącznikowym są rozpatrywane różne funkcje kopuli.

Rysunki 1, 2 i 3 przedstawiają wyniki uzyskane w rezultacie zastosowania różnych modeli. Panel górny przedstawia korelację uzyskaną w wyniku zastosowania modelu wielowymiarowego $\operatorname{VAR}(1)-\mathrm{GARCH}(1,1)$, panel środkowy przedstawia zmiany współczynnika Spearmana w wyniku zastosowania modelu z dwoma reżimami, natomiast panel dolny przedstawia zmiany współczynnika Spearmana w wyniku zastosowania modelu $\mathrm{z}$ trzema reżimami.

Rysunek 1 przedstawia dynamiczną korelację warszawskiej Giełdy Papierów Wartościowych z giełdami Czech, Węgier, Turcji oraz Rosji. Analizując wykresy, zauważamy, ze siła związku indeksu WIG z indeksami giełdowymi pochodzącymi z rynków Europy Wschodniej ulega dużym wahaniom.

Zmiany współzależności WIG z indeksem rynku węgierskiego oraz czeskiego są do siebie podobne. Wszystkie te kraje należą bowiem do Grupy Wyszehradzkiej. Dynamiki współzależności WIG z indeksem rynku rosyjskiego oraz rynku tureckiego również charakteryzują się podobieństwem do siebie.

Do 2005 roku współzależność WIG z indeksami giełdowymi krajów pochodzących z rynków Europy Wschodniej jest stosunkowo mała i dopiero po tym roku ulega zwiększeniu. Wyższy poziom współzależności oscyluje wokół wartości 0,6 i wydaje się podobny dla wszystkich analizowanych tu rynków. Wydaje się jednak, że w okresie globalnego kryzysu finansowego współzależność jest trochę wyższa i dynamiczny współczynnik Spearmana osiąga stan około 0,7 we wszystkich badanych przypadkach. Jednakże tylko w przypadku Rosji i Turcji czas przebywania w stanie $\mathrm{z}$ tak wysoką korelacją jest stosunkowo długi. Wyższe poziomy zależności utrzymują się do przełomu lat 2012 i 2013. Następnie zauważamy osłabienie tych współzależności, które utrzymuje się do końca okresu naszego badania.

Rysunek 2 przedstawia dynamikę współzależności naszej giełdy z wybranymi rynkami Europy Zachodniej. Zauważamy, że charakter tej zależności zbliżony jest 

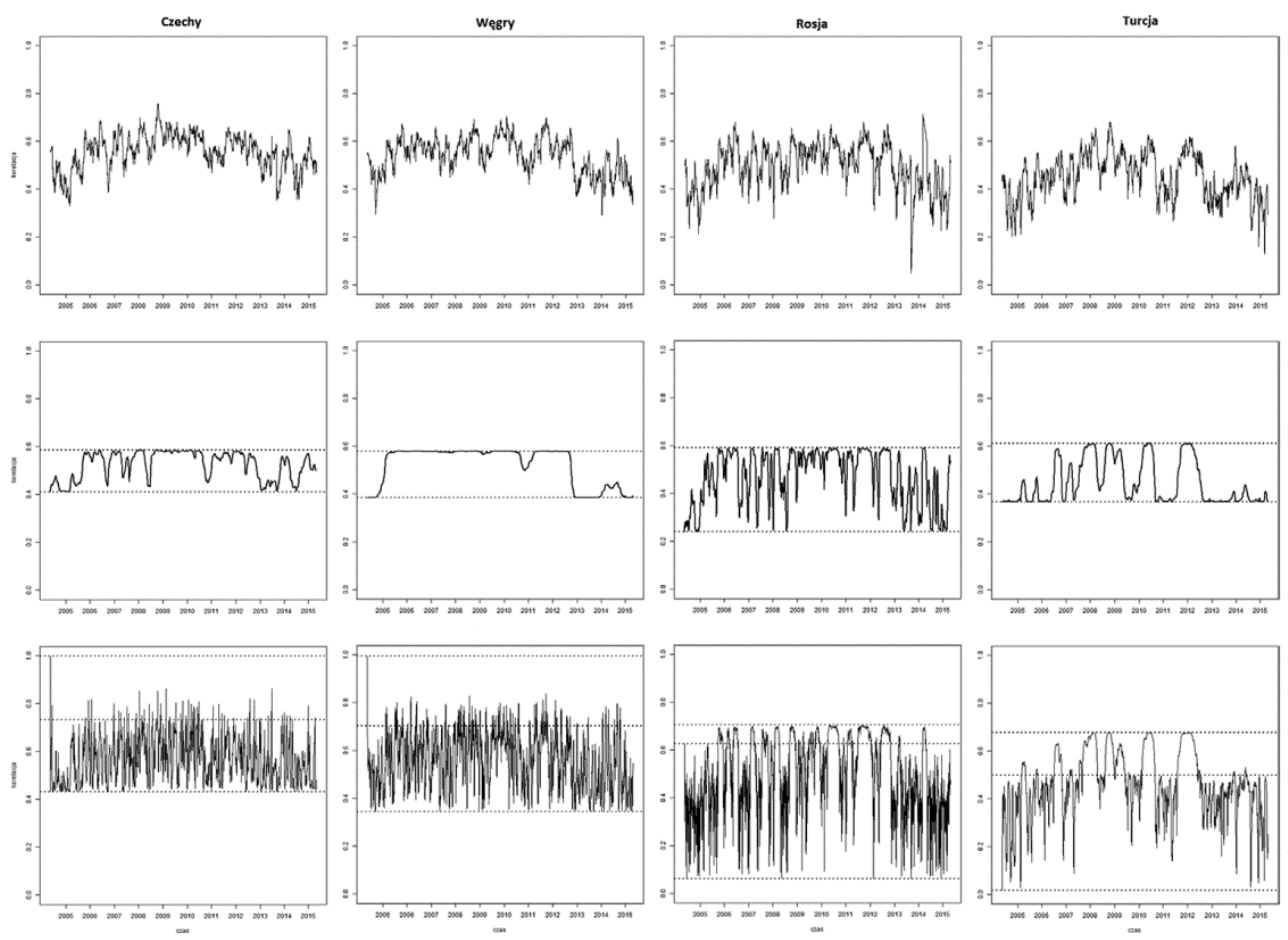

Rys. 1. Dynamiczna korelacja warszawskiej GPW z giełdami Europy Wschodniej.

Panel górny przedstawia korelację uzyskaną w wyniku zastosowania modelu wielowymiarowego VAR(1)-GARCH(1,1), panel środkowy przedstawia zmiany współczynnika Spearmanna w wyniku zastosowania modelu $\mathrm{z}$ dwoma reżimami, natomiast panel dolny przedstawia zmiany współczynnika Spearmanna w wyniku zastosowania modelu z trzema reżimami

Źródło: opracowanie własne.

do przypadków obserwowanych w Europie Wschodniej, tj. po początkowo dość niskiej wartości korelacji nastąpiło przejście na stan wyższej współzależności. Jednak w analizie powiązań WIG z indeksami pochodzącymi z Europy Zachodniej zauważamy, że przejście na wyższy stan jest obserwowane w późniejszym okresie niż miało to miejsce $\mathrm{w}$ analizie powiązań WIG z rynkami Europy Wschodniej. Zwiększenie tej współzależności nastąpiło po 2006 roku i może to być związane z faktem przystąpienia Polski do grupy G6. Do grupy tej należały wcześniej Francja, Hiszpania, Niemcy, Wielka Brytania i Włochy. W relacjach z Austrią nie obserwujemy bowiem tak jednoznacznych przejść na wyższy poziom, jak w relacjach z krajami z grupy G6.

Podobnie jak w poprzedniej analizie, zwiększenie współzależności może być związane z występowaniem kryzysu globalnego, którego początek przypada na rok 2007. W okresie tym obserwujemy występowanie trzeciego stanu, w którym wystę- 
puje bardzo silna korelacja pomiędzy badanymi indeksami giełdowymi. Pomimo że czas przebywania $\mathrm{w}$ tym stanie jest relatywnie krótki, to jednak występuje on dość często. Podobnie jak w analizie powiązania WIG z indeksami Europy Wschodniej, na przełomie lat 2012 i 2013 również następuje spadek siły zależności GPW od rynków Europy Zachodniej. Można zatem zauważyć, że tendencja do osłabienia relacji warszawskiej GPW z innymi rynkami jest powszechna w całej Europie.
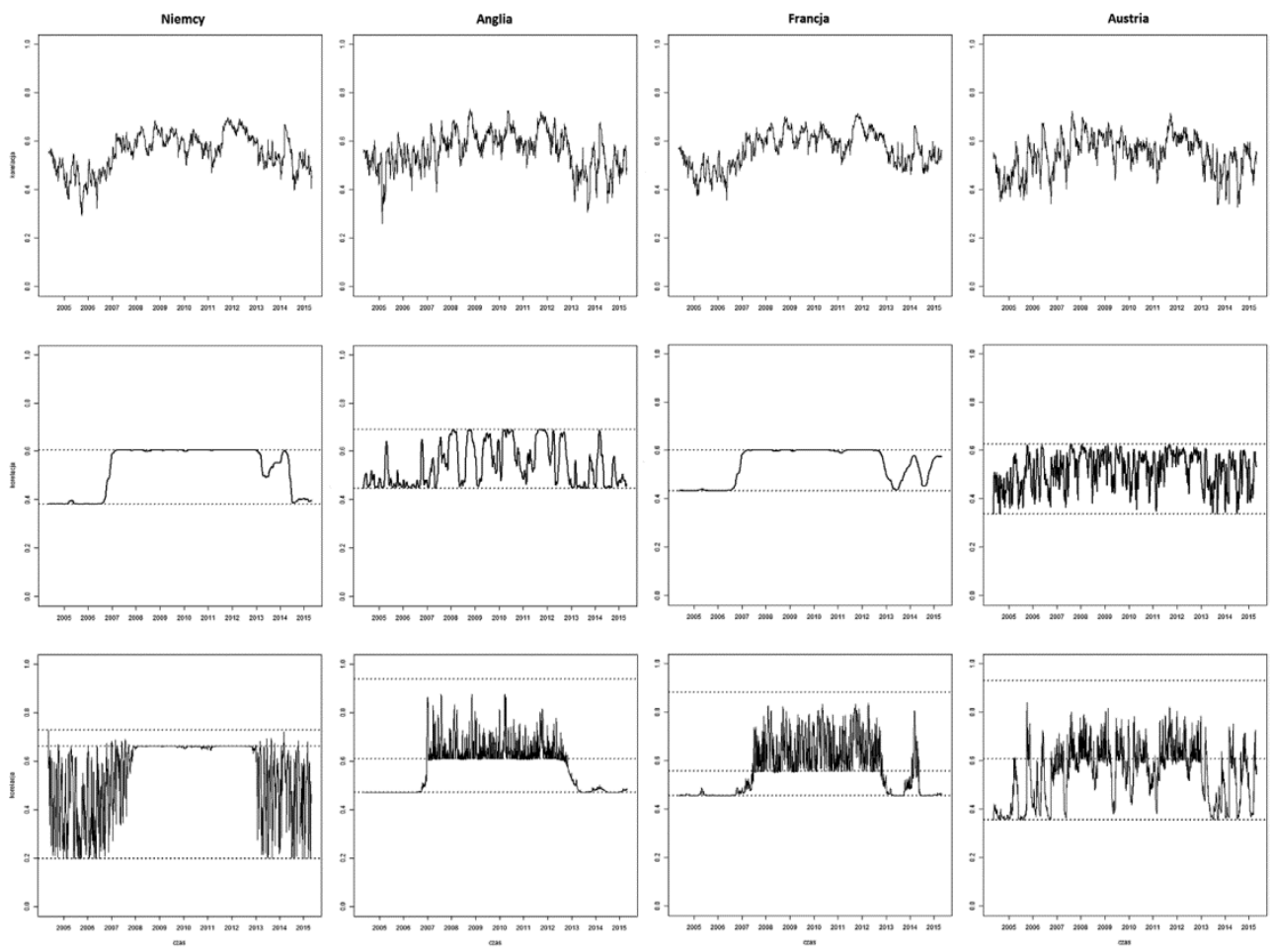

Rys. 2. Dynamiczna korelacja warszawskiej GPW z giełdami Europy Zachodniej. Panel górny przedstawia korelację uzyskaną $\mathrm{w}$ wyniku zastosowania modelu wielowymiarowego VAR(1)-GARCH(1,1), panel środkowy przedstawia zmiany współczynnika Spearmana w wyniku zastosowania modelu $\mathrm{z}$ dwoma reżimami, natomiast panel dolny przedstawia zmiany współczynnika Spearmanna w wyniku zastosowania modelu z trzema reżimami

Źródło: opracowanie własne.

Na koniec przedstawimy wybrane wyniki dotyczące badań dynamiki współzależności między WIG i amerykańskim indeksem giełdowym oraz między WIG i indeksami reprezentującymi wybrane rynki azjatyckie. Dynamika korelacji jest przedstawiona na rys. 3 .

$\mathrm{W}$ analizie tych współzależności spotykamy się z problemem występowania różnic czasowych między tymi regionami. Zatem do analizy współzależności giełd azja- 
tyckich z naszym rynkiem wzięliśmy kursy zamknięcia giełd azjatyckich z tego samego dnia co kurs zamknięcia naszej giełdy, natomiast w ramach analizy giełdy amerykańskiej pod uwagę były brane kursy zamknięcia $\mathrm{z}$ dnia poprzedniego.
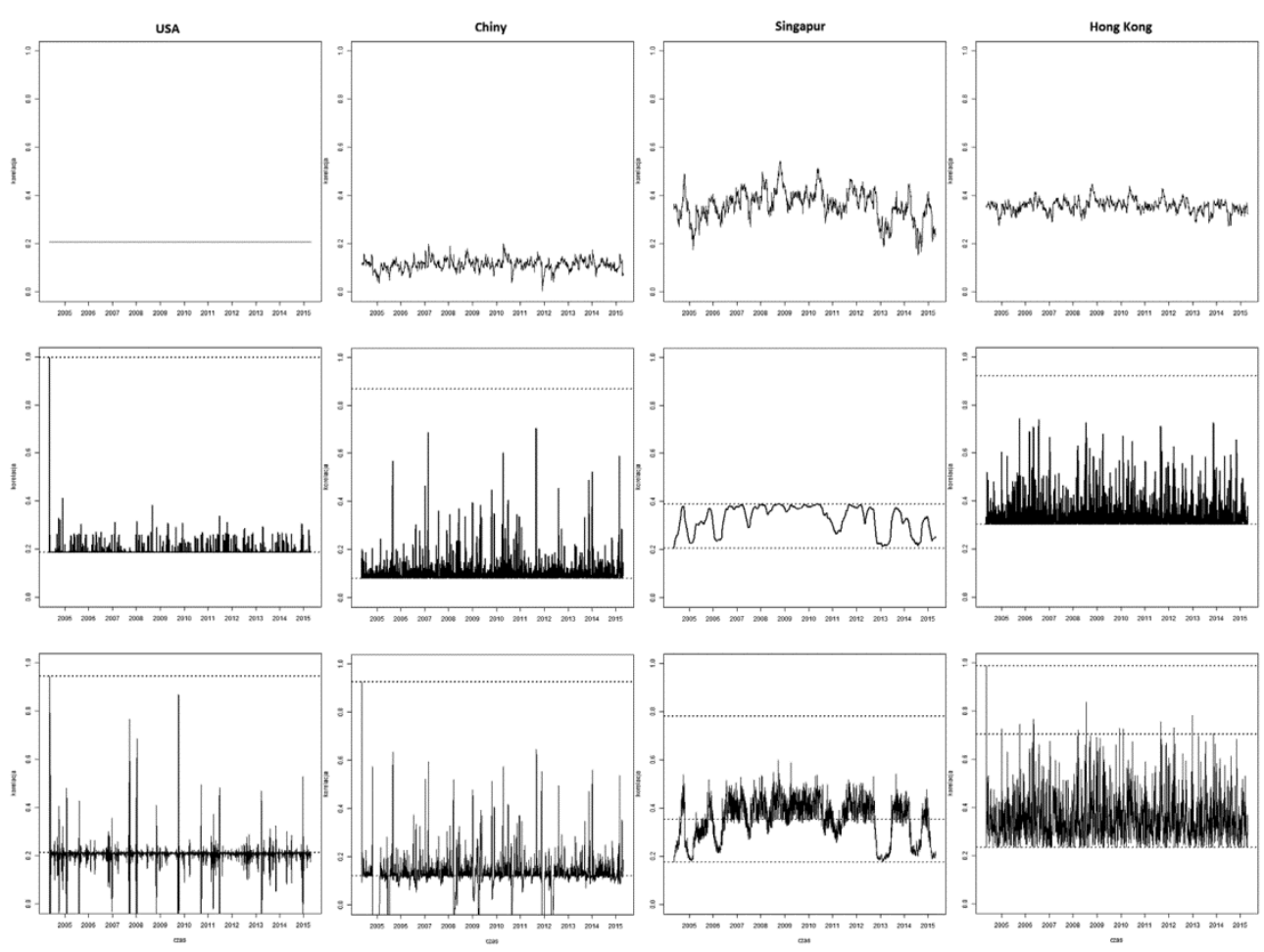

Rys. 3. Dynamiczna korelacja warszawskiej GPW z giełdami Azji i Ameryki. Panel górny przedstawia korelację uzyskaną $\mathrm{w}$ wyniku zastosowania modelu wielowymiarowego VAR(1)-GARCH(1,1), panel środkowy przedstawia zmiany współczynnika Spearmanna w wyniku zastosowania modelu $\mathrm{z}$ dwoma reżimami, natomiast panel dolny przedstawia zmiany współczynnika Spearmanna w wyniku zastosowania modelu z trzema reżimami

Źródło: opracowanie własne.

Analizując wyniki dotyczące współzależności, zauważamy bardzo słabą dynamikę zmian. W odniesieniu do rynku amerykańskiego współczynnik korelacji Spearmanna jest utrzymany na poziomie około 0,2 przez cały okres badania. W przypadku rynków azjatyckich dynamika jest również niewielka. Dwa stany zależności można wyodrębnić w ramach rynków Singapuru, Korei i Indii. Pomimo że oba stany definiują dość słabą zależność (około 0,2 dla niższego stanu i około 0,4 dla stanu wyższego), można przypuścić, że zależność między tymi rynkami osiągnęła wyższy stan w okresie globalnego kryzysu. 


\section{Zakończenie}

Celem pracy była analiza dynamiki współzależności indeksu WIG z innymi głównymi indeksami światowymi w okresie po wstąpieniu Polski do Unii Europejskiej. Badanie miało na celu potwierdzenie panującej tezy, że w okresie kryzysu zwiększyły się powiązania rynku GPW w Warszawie z innymi rynkami finansowymi.

Do modelowania zastosowano podejście oparte na funkcji połączeń sterowanych ukrytym procesem Markowa oraz wielowymiarowy model GARCH. Przeprowadzone badanie pozwoliło na wyodrębnienie okresów silniejszych i słabszych współzależności rynku polskiego z rynkami finansowymi wybranych krajów.

Współzależność Polski z rynkami Europy ulega ciągłym zmianom. Można w niej wyodrębnić dwa stany: stan słabej współzależności oraz stan umiarkowanej współzależności. W niektórych przypadkach zauważalny jest również stan trzeci. Po początkowej bardzo słabej korelacji WIG z indeksami giełd europejskich następuje wzrost tej zależności około 2005 roku w odniesieniu do giełd Europy Wschodniej oraz około 2006 roku w przypadku wybranych giełd Europy Zachodniej. Zwiększenie tej współzależności, które nastąpiło po 2006 roku, może być związane z przystąpieniem Polski do grupy G6. Wydaje się, że indeks WIG ma relatywnie silniejsze współzależności z indeksami giełd Europy Zachodniej niż z indeksami giełd Europy Wschodniej. W analizie powiązań WIG z giełdami Europy Zachodniej zauważamy istnienie stanu, w którym występuje bardzo silna korelacja.

Rozpatrywane osobno zmiany współzależności WIG z indeksami giełdowymi krajów Europy Wschodniej oraz krajów Europy Zachodniej wykazują jednak pewne podobieństwa $\mathrm{w}$ charakterze dynamiki: zauważalny wzrost współzależności w czasach kryzysu oraz zauważalne osłabienie współzależności po 2012 roku.

W odniesieniu do giełdy amerykańskiej współzależność utrzymuje się na tym samym poziomie przez cały okres badania. Bardzo słabą dynamikę obserwujemy w ramach analizy rynków azjatyckich. Jednakże dla niektórych z nich widoczny jest nieznaczny wzrost siły współzależności w okresie kryzysu.

Wydaje się zatem, że na tle rynków innych kontynentów współzależność WIG $\mathrm{z}$ europejskimi indeksami giełdowymi odznacza się największą dynamiką. Pomimo że w czasach globalnego kryzysu zauważamy wzrost korelacji z niektórymi rynkami azjatyckimi, to zmiana ta jest stosunkowo nieduża.

Wydaje się, że różny charakter współzależności WIG z indeksami giełdowymi innych krajów wynika z ich geograficznej lokalizacji, a co za tym idzie - z istnienia różnych stref czasowych. 


\section{Literatura}

Chollete L., Heinen A., Valdesogo A., 2009, Modeling international financial returns with a multivariate regime switching copula, Journal of Financial Econometrics, 7(4), s. 437-480.

Czapkiewicz A.,. Basiura B., 2014, The position of the WIG index in comparison with selected market indices in boom and bust periods, Statistics in Transition, 15(3), s. 427-436.

Diebold F.X., Gunther T.A., Tay A.S., 1989, Evaluating density forecasts with application to financial risk management, International Economic Review 39(4), s. 863-883.

Doman M., Doman R., 2013, The Dynamics and Strength of Linkages between the Stock Markets in the Czech Republic, Hungary and Poland after their EU Accession, Dynamic Econometric Models, vol. 13, s. 5-31.

Engle R.F., 2002, Dynamic conditional correlation: a simple class of multivariate generalized autoregressive conditional heteroskedasticity models, Journal of Business and Economic Statistics, 20, s. 339-350.

Forbes K., Rigobon R., 2002, No contagion, only interpedence: Measuring Stock Market Comovements, The Journal of Finance, 10(5), s. 2223-2261.

Grubel H., 1968, Internationally diversified portfolios: Welfare gains and capital Flows, American Economic Review, 58(5), s. 1299-1314.

Hamilton J.,1994, Time Series Analysis, Princeton University Press, Princeton.

Hołubowicz K., 2014, Korelacja indeksów cen akcji na globalnych rynkach finansowych, Nauki o Finansach, 2(19).

Jondeau E., Rockinger M., 2006, The Copula-GARCH model of conditional dependencies: An international stock market application, Journal of International Money and Finance, 25, s. 827-853.

Kenourgios D., Samitas A., Paltalidis N., 2011, Financial crises and stock market contagion in a multivariate time-varying asymmetric framework, Journal of International Financial Markets, Institutions \& Money, 21(1), s. 92-106.

Longin F., Solnik B., 1995,Is the correlation in international equity returns constant: (1960-1990), Journal of International Money and Finance, 14, s. 3-26.

Markwat T., Kole E., van Dijk D., 2009, Contagion as a domino effect in financial markets, Journal of Banking \& Finance, 33(11), s. 1996-2012.

Patton A.J., 2009, Copula-based Models for Financial Time Series, Handbook of financial time series, Springer, Berlin, s. 767-785.

Pekota G., 2007, Analiza zależności między indeksami rynków akcji na giełdzie polskiej i amerykańskiej, Badania Operacyjne i Decyzje, nr 3-4, s. 133-145.

Rodriguez J.C., 2007, Measuring Financial Contagion: A Copula Approach, Journal of Empirical Finance, 14(3), s. 401-423.

Tse Y.K., Tsui A.K.C., 2002, A Multivariate Generalized Autoregressive Conditional Heteroscedasticity Model with Time-Varying Correlations, Journal of Business and Economic Statistics, 20, s. 351-362.

Sklar A., 1959, Fonctions de répartition à n Dimensions et Leurs Marges, Publication's de l'Institut de Statistiques de l'Université de Paris, Paris, s. 229-231.

Vuong Q.H., 1989, Likelihood Ratio Tests for Model Selection and Non-nested Hypotheses, Econometrica, 57 (2), s. 307-333. 